九州大学学術情報リポジトリ

Kyushu University Institutional Repository

FIELD STUDIES ON THE BIOLOGICAL CONTROL OF LEAFHOPPERS AND PLANTHOPPERS (HEMIPTERA : HOMOPTERA) INJURIOUS TO RICE PLANTS IN SOUTHEAST ASIA. PROGRESS REPORT FOR THE YEAR 1977

Hirashima, Yoshihiro

Aizawa, K.

Miura, Tadashi

Wongsiri, T.

https://doi.org/10.5109/2384

出版情報: ESAKIA. 13，pp.1-20，1979-03-10. Entomological Laboratory，Faculty of Agriculture， Kyushu University

バージョン：

権利関係 : 


\title{
FIELD STUDIES ON THE BIOLOGICAL CONTROL OF LEAFHOPPERS \\ AND PLANTHOPPERS (HEMIPTERA : HOMOPTERA) INJURIOUS TO RICE PLANTS IN SOUTH-EAST ASIA. PROGRESS REPORT FOR THE YEAR $1977^{12) 3)}$
}

\author{
Y. Hirashima, K. Aizana, T. Miura and T. Wongsiri \\ Entomological Laboratory, Faculty of Agriculture, Kyushu University, \\ Fukuoka 812, Japan: Institute of Biological Control, Faculty of Agri- \\ culture, Kyushu University, Fukuoka 812. Japan : Entomological Labora- \\ tory, Faculty of Agriculture, Shimane University, Matsue 690, Japan; \\ and Division of Entomology and Zoology, Department of Agriculture, \\ Bangkhen, Bangkok 9, Thailand
}

\section{INTRODUCTION}

Rice leafhoppers and planthoppers have been an important menace to rice in Asian countries not only because of their severe damage due to their abundance but also of their ability to transmit virus diseases of this important food plant. Control of these homopterous insect pests includes many difficult problems. In the field of biology, the development of various biotypes of the brown planthopper recently observed in some Asian countries is apparently one of these. In Japan, outbreaks of the white-backed planthopper and the brown planthopper due to their long distance trans-ocean migration have been one of the most serious problems in applied entomology for many years. Some important species of the rice hoppers occur throughout Asia, and each country has nearly the same problems with these pests. Thus, it is understood today that co-operative studies among countries concerned can only contribute toward successful control of these pests.

Our project aims at to find out primarily insect natural enemies as well as pathogens of microbial diseases of rice leafhoppers and planthoppers in countries in South-East Asia in order to conrtibute toward the basic study of the biological control of these pests.

1) Partial result of Grant-in-Aid for Overseas Scientific Survey (1977) from the Ministry of Education, Science and Culture, Japanese Government.

2) Publication of this paper was financially supported by grant No. 304329 (Principal investigator: Y. Hirashima), the Ministry of Education, Science and Culture, Japanese Government.

3) Contribution from the Entomological Laboratory, Faculty of Agriculture, Kyushu University, Fukuoka (Ser. 3, No. 57). 
The present paper reports an outline of field studies made in Thailand in 1977 in collaboration with Thai scientists.

In this paper the term paddy is used only for the rice field, not for rice itself. Thus, rice paddy means rice field.

Acknowledgement: We are very grateful to Dr. K. Yasumatsu, Emeritus Professor of Entomology, Kyushu University, and Rice Pest Control Specialist by Colombo Plan stationed at Bangkok, for his kind advice and assistance in many ways given to us in the course of the present study. Without his assistance fruitful field studies and activities could not be done. We are also grateful to the National Research Council of Thailand (Secretary-General: Dr. Pradisth Cheosakul) for the approval of conducting field studies in Thailand. We are also very thankful to Thai collaborators involved in this project, whose names are appeared in the text, and other entomologists at Department of Agriculture, Bangkok, and to the representatives of San Pa Tong Rice Experiment Station, Fang Agricultural Experiment Station, Chainat Rice Experiment Station and Agriculture Center Northeast for their kind help and assistance. Without helpful assistance of these ladies and gentlemen our field studies could not be done successfully.

Acknowledgement is made to the Ministry of Education, Science and Culture, Japanese Government, for financial support of the present overseas field research and for printing of this paper.

\section{ORGANIZATION}

Wongsiri and Hirashima agreed early in 1976 to conduct field studies on the natural enemies of rice hoppers in Thailand in 1977 by a group of Japanese and Thai scientists. Aizawa and Yano, in addition to Hirashima, were supposed to join from Japan. Consulted with Dr. Yasumatsu, an itinerary was made soon after. This proposal was then approved by the Ministry of Education, Science and Culture, Japanese Government as one of overseas field researches for the year 1977 and later by the $\mathrm{N}$ ational Research Council of Thailand. Toward the spring of 1977, Dr. K. Yano was transferred from Kyushu University to Yamaguti University, and because of his new situation he could not join to us. Then Miura was approved. Thus, the project was organized as follows:

Project leader and principal investigator

Yoshihiro Hirashima, Professor of Entomology, Kyushu University, Fukuoka. Special field of research: Insect natural enemies of rice hoppers, specially Hymenoptera, Diptera and Strepsiptera.

Japanese investigators

Keio Aizawa, Professor of Biological Control, Kyushu University, Fukuoka. Special field of research : Microbial diseases of rice hop- 
pers.

Tadashi Miura, Associate Professor of Entomology, Shimane University, Matsue. Special field of research : Hymenopterous egg parasites of rice hoppers and ecology of the latter.

Thai investigator

Tanongchit Wongsiri, Director, Division of Entomology and Zoology, Department of Agriculture, Bangkok. Special field of research: Insect natural enemies of rice hoppers.

Thai collaborators :

Preecha Vungsilabatr, Entomologist, Division of Entomology and Zoology, Department of Agriculture, Bangkok.

Chirapanthu Chandratat, Entomologist, San Pa Tong Rice Experiment Station, San Pa Tong.

Chantanee Hengsawad (Mrs.), Entomologist, San Pa Tong Rice Experiment Station, San $\mathrm{Pa}$ Tong.

Pethatai Pati-rupanusara (Mrs.), Entomologist, Chainat Rice Experiment Station, Chainat.

Tawat Pati-rupanusara, Plant Pathologist, Chainat Rice Experiment Station, Chainat.

Weerawooth Katanyukul, Entomologist, Agriculture Center Northeast, Thapra, Khon Kaen.

General advisor

Keizo Yasumatsu, Emeritus Professor of Entomology, Kyushu University, and Rice Pest Control Specialist, Colombo Plan, c/o Division of Entomology and Zoology, Department of Agriculture, Bangkhen, Bangkok.

\section{ITINERARY AND AREAS VISITED}

After arrival of Hirashima, Aizawa and Miura at Bangkok on 26 September 1977, 25 locations listed below were visited and field studies of natural enemies of rice hoppers were made.

\section{San Pa Tong 30 September-31 October}

Excellent facilities were provided and a Landrover for field trips and transportation between Chiang Mai and San Pa Tong, about $30 \mathrm{~km}$ south-west of Chiang Mai, was generously offered by San Pa Tong Rice Experiment Station. Several locations in the San $\mathrm{Pa}$ Tong area were visited for field studies. At Rice Experiment Station, samplings were made on 3, 14, 18 and 28 October in rice paddies. A 5-day trip to Fang, accompanied by $\mathrm{Mr}$. Chirapanthu, was also made during our stay at San $\mathrm{Pa}$ Tong. Insects living outside rice paddies were also collected in this area.

Very unfortunately, many districts of Thailand were suffered with drought 


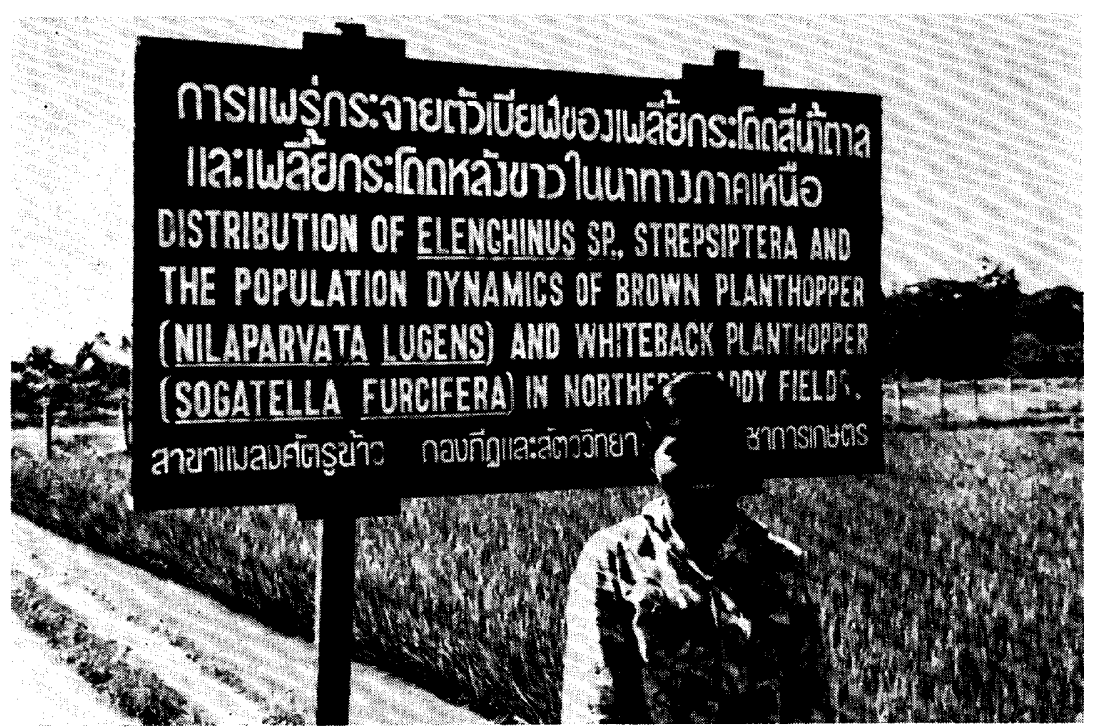

Fig. 1. Mrs. Chantanee, entomologist at San Pa Tong Rice Experiment Station, stands in her rice paddy schemed to the observation of a stylopid, Elenchus yasumatsui, parasitic on the brown planthopper and the white-backed planthopper.

this year. We were told that starting of rice cultivation was delayed in the San $\mathrm{Pa}$ Tong area because of the shortage of water, but rice growing was good.

Lamphun 6 October

Doi Saket 6 October

Chom Thong 11 October

Hot 11 October

Lampang 13 October

Mae Taeng 17 October

Chiang Dao 17 October

About $75 \mathrm{~km}$ north of Chiang Mai along the highway.

Fang 23 October-27 October

Fang is located about $150 \mathrm{~km}$ north of Chiang Mai and near by the Burma border. Excellent facilities were provided by Fang Agricultural Experiment Station. Field studies of natural enemies of rice hoppers were made in Fang on 25 and 26 October. Many insects, especially ants, were also collected in Fang. A collecting trip to the border (Tha Ton) via Mae Ai was also made on 25 October.

Mae Ai 25 October

Chai Nat 3 November-23 November

Excellent facilities as well as a Landrover for field trips were provided by Chainat Rice Experiment Station. Several locations in the Chai Nat area were visited for field studies. Samplings were made in rice paddies in the site for 


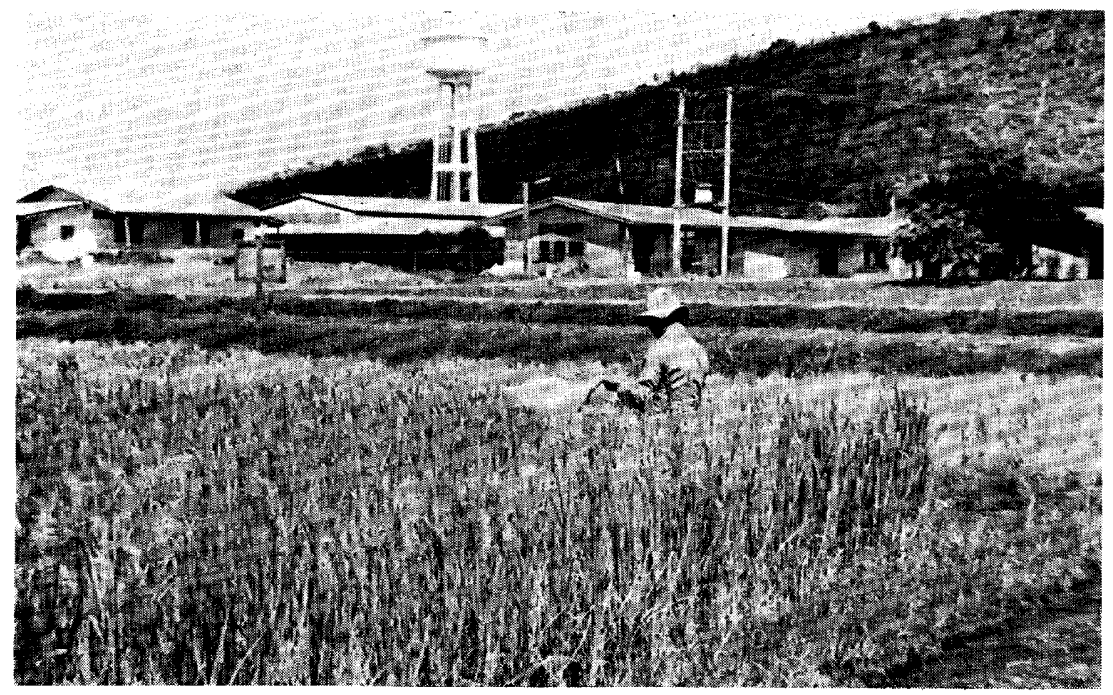

Fig. 2. Sampling of natural enemies of rice hoppers at Chainat Rice Experiment Station,

Chainat Rice Experiment Station on 4, 11, 18 and 22 November. A 3-day trip was made for field studies by a taxi cab to Tak and as far north as Thoen, about $80 \mathrm{~km}$ south of Chiang Mai, from 4 November accompanied by Mr. Tawat.

Rice cultivation in this area was good except for Thoen, Ban Mae Chung Rai, Kamphaeng Phet and Khanu Woralaksaburi where we observed unfortunate severe damages to the rice cultivation because of drought.

In Buri 7 November

Chai Yo 7 November

Kahnu Woralaksaburi 9 November

About $105 \mathrm{~km}$ north of Chai Nat along the highway and $9 \mathrm{~km}$ east of it.

Phayuhakhiri 9 November

About $30 \mathrm{~km}$ north of Chai Nat.

Kamphaeng Phet 14 November

About $180 \mathrm{~km}$ north of Chai Nat along the highway. This location was visited on our way to Tak from Chai Nat.

Thoen 15 November

About $93 \mathrm{~km}$ north of Tak and about $200 \mathrm{~km}$ south of Chiang Mai along the highway.

Ban Mae Chung Rai 15 November

About $30 \mathrm{~km}$ south of Thoen along the highway.

Tak 16 November

Khon Kaen 25 November-7 December

Aizawa left Bangkok for Japan on 25 November. Excellent facilities were 
provided and a Landrover for field trips was offered by Khon Kaen Agricultural Experiment Station (Agriculture Center Northeast). Several locations in the Khon Kaen area were visited for field studies and for collecting insects. It was a dry season and collecting was not good. Sampling of natural enemies of rice hoppers in the city of Khon Kaen was done on 29 November only. One day trip for field observation of insects was made on 1 December to Non Khai, a town by the Mecong on the Laos border and to Ban Chiang, a village of fame in the field of archaeology, located about $50 \mathrm{~km}$ east of Udon Thani.

Very unfortunately, severe damages to rice were also seen in this area, due to drought attacked Thailand this year.

Chum Pae 28 November

Chumpae Rice Experiment Station, about $85 \mathrm{~km}$ west of Khon Kaen, was visited for sampling, accompanied by Dr. Weerawooth who kindly drove.

Kalasin 29 November

About $80 \mathrm{~km}$ east of Khon Kaen.

Udon Thani 1 December

Hin Kong 2 December

About $35 \mathrm{~km}$ north of Khon Kaen.

Nam Pong 6 December

About $30 \mathrm{~km}$ north of Khon Kaen. Ubol Ratana Dam, $30 \mathrm{~km}$ west of Nam Pong, was also visited for collecting insects.

\section{SAMPLING METHODS}

Four species of rice hoppers most injurious to the rice plant, i. e., the green rice leafhoppers, Nephotettix virescens Distant and Nephotettix nigropictus Stål, the white-backed planthopper, Sogatella furcifera Horvath, and the brown planthopper, Nilaparvatalugens Stăl, were the main target pests of rice with which our field research was primarily concerned. Special emphasis was made to find out the hymenopterous egg parasites, dryinid wasps, ants, pipunculid flies and stylopids as well as microbial diseases as the natural controlling agency of the increase of these pests.

Three sampling methods were adopted for collecting rice hoppers and their egg and nymphal and adult parasites, as follows:

\section{Method I}

Sweeping by an insect net, $42 \times 80 \mathrm{~cm}$ with a handle of $90 \mathrm{~cm}$ in length, in the rice paddy is a most simple but still effective method to collect rice hoppers as well as their insect natural enemies and spiders. Fourty sweeps were made for one unit. For a rice paddy of about $1,250 \mathrm{~m}^{2}, 3$ units $(2$ at the periphery and 1 at the center) were made for one grand unit. All the animals thus collected were anesthetized by ether in a plastic bag and then killed by cyanide or alcohol appropriate to keep them as good specimens. In 
the laboratory they were sorted out to species and individual numbers of them were counted.

\section{Method II}

A hill of rice was covered all of a sudden by an insect net used in the method I and then the hill was cut from just above the root. All the animals thus collected in the net were treated as in the method I. Ten hills of rice were chosen at random for one unit for a rice paddy of about $1,250 \mathrm{~m}^{2}$. All the rice stems thus cut and brought back to the laboratory were carefully examined one by one for the eggs of rice leafhoppers and planthoppers. When the egg-mass of hoppers was found, it was put into a small glass tube for rearing. Nymphs of the hoppers as well as the adults of parasitic wasps emerged from the egg were carefully identified.

\section{Method III}

An aspirator was used to suck up the hoppers, both nymphs and adults, from the rice hill. Ten hills were examined for one unit in one rice paddy. All the hoppers thus collected were kept alive and carefully examined for the parasites and diseases under the binocular microscope. When the parasitized hoppers were found, they were reared separately in a small glass tube for further examination.

For collecting ants in rice paddies, 3 different methods were combined for one grand unit of sampling, as follows:

1. Collecting ants on the boundary (or bank) of rice paddy by an aspirator for 30 minutes for one unit. Area of about $30 \mathrm{~m}$ long and $1 \mathrm{~m}$ wide of the boundary was covered by one unit on an average. This is a good method for collecting ground-nesting ants. Special attention has to be paid, however, to collect as many species of ants as possible in the limited time.

2. Sweeping by an insect net, used in the method I, over weeds on the boundary of rice paddy; 100 sweeps for one unit.

3. Sucking ants by an aspirator for 30 minutes for one unit on the stems and leaves of rice, especially on the lower part of the rice hill where sometimes they nest.

\section{RESULTS OBTAINED}

In this chapter only a few of our findings and observations are reported due to the shortage of time to analyze the material we obtained.

\section{(A) Hymenopterous egg parasites}

Yasumatsu et al. (1975) reported 3 species of Trichogrammatidae (Paracentrobia yasumatsui, Paracentrobia garuda and Oligosita sp.) and 4 species of Mymaridae (Anagrus optabilis, Mymar taprobanicum, Polynema sp. and Gonatocerus sp.) are important as egg parasites of rice leafhoppers and planthoppers in Thailand. 
During our field studies, painstaking efforts were made to investigate the egg parasites of rice leafhoppers and planthoppers in the 25 locations stated above. We were able to find out 4 species of egg parasites, i. e., Paracentrobia sp., Oligosita sp., Anagrus optabilis and Gonatocerus sp.

From the egg-masses of the white-backed planthopper, we reared Oligosita sp. and Anagrus optabilis.

Oligosita sp. was found in rice paddies of Chiang Dao and Mae Theng only. These two locations are in northern part of Thailand. Anagrus optabilis was found in rice paddies of Doi Saket, Lamphun, San $\mathrm{Pa}$ Tong, Chom Thong, Hot and Chai Nat. This parasitic wasp was fairly abundant in these areas. The percentage parasitism of it was $100 \%$ to the egg-mass of the white-backed planthopper in Doi Saket, while it was $14.2 \%$ in Chai Nat. The latter was the lowest.

From the egg-masses of the brown planthopper, we reared Anagrus optabilis. The latter was obtained in San Pa Tong only.

From the eggs of the green rice leafhoppers, we reared Paracentrobia sp. and Gonatocerus sp. Undoubtedly two species of leafhoppers, Nephotettix virescens and N. nigropictus, were mixed up in our field study, because the egg or eggmass of them are very similar to each other, and these are treated as the green rice leafhoppers in this paper. Paracentrobia sp. was collected from rice paddies at Mae Taeng, Doi Saket, Khon Kaen, Chum Phae and Nam Phong. The percentage parasitism of this wasp to the green rice leafhoppers was very high in these locations. Gonatocerus sp. was obtained from Fang, San Pa Tong, Phayuhakhiri and Chai Nat. Percentage parasitism of this species to both the egg-masses and individual eggs in an egg-mass was also very high at Fang, Phayuhakhiri and Chai Nat.

Very interestingly, Paracentrobia sp. and Gonatocerus sp. were found to be ecologically similar species which are parasitic even on the same egg-mass of the green rice leafhoppers. These two egg parasites were found simultaneously in the same rice paddies at Mae Ai, Chiang Dao, Lamphun, Chom Thong, Thoen, Ban Mae Chung Rai, Tak, Kamphaeng Phet, Chai Nat, Kalasin, Hin Kong and Udon Thani. In these cases, Gonatocerus sp. was dominant in Mae Ai,Chiang Dao, Chom Thong, Thoen, Tak, Kamphaeng Phet, Chai Nat (I), Kalasin, Hin Kong and Udon Thani, while Paracentrobia sp. was dominant in Lamphun, Ban Mae Chun Rai and Chai Nat (IV). Miura (1976), one of the co-authors of this paper, reports a similar phenomenon in Japan: Paracentrobia andoi and Gonatocerus sp. on the eggs of Nephotettix cincticeps. According to Yasumatsu (personal communication), Gonatocerus sp. of Japan and Thailand involved probably belong to the same species.

The fourth species of the parasitic wasp, Oligosita sp. was collected by sweeping cnly. It was collected from rice paddies of Fang, San $\mathrm{Pa}$ Tong, Tak and Chai Nat. This species is parasitic on the eggs of the white-backed plant- 
hopper, and its percentage parasitism is very high at a certain time of year (Yasumatsu, personal communication).

Results of our field studies on the egg and nymphal parasites of rice leafhoppers and planthoppers will be reported in more detail in a separate paper (Miura, Hirashima and Wongsiri, 1979).

\section{(B) Dryinid wasps}

Wasps belonging to the family Dryinidae are known to be parasitic primarily on the planthoppers. As a result of our investigations, at least two species of the dryinid wasps were found in the rice paddy in many locations. Probably they belong to two genera, Agonatopus and Haplogonatopus. Larvae of these wasps were also detected from the white-backed planthopper, the brown planthopper and the rice green leafhoppers (Miura, Hirashima, and Wongsiri, 1979).

Adults of the dryinid wasps were not rare. In Chai Nat, for example, at least one adult specimen of Agonatopus sp., a black species, was collected every 90 sweeps in the rice paddy. Taxonomic study of wasps is being undertaken.

(C) Ants

Ants have never been paid attention as the predator of rice pests, but we think they are fairly important natural controlling agency of these pests. Unexpectedly large number of species as well as individuals of ants were collected in rice paddies in Thailand by our field studies, both on the rice hill (leaves and stems of rice) and in rice paddies (both on the boundary and the soil surface of rice paddy when dried).

Prenolepis longicornis was frequently found nesting in the rice hill, especially toward the lower part of it, even though the rice paddy was filled with water. Observations on this species whether this is beneficial or harmful to rice were not made, however.

Tetraponera rufonigra is a large and fierce ant known also by its very painful sting. Its inhabiting rice paddy is rather uncommon, but we collected some workers of this ant in rice paddies. In Fang, we witnessed a worker of this ant, on the leaf of rice, jumped on and caught an adult of the green rice leafhopper by her mandibles.

We caught at least 16 species of ants in the rice paddies by sweeping. They belong to 14 genera, i. e., Tetraponera, Diacamma, Cardiocondyla, Pheidole, Pheidologeton, Monomorium, Solenopsis, Tetramorium, Iridcwyrmex, Tapinoma, Plagioletis, Prenolepis, Camponotus and Polyrhachis.

Another example of our ant collection on the rice paddy boundary, by an aspirator for 30 minutes, at Tak on 15 November, by Hirashima, is shown below.

Species

Odontoponera transversa
No. of specimens taken 


$\begin{array}{lr}\text { 2. Diacamma sp. } & 5 \\ \text { 3. Camponotus sp. } & 7 \\ \text { 4. Plagiolepis longipes } & 22 \\ \text { 5. Prenolepis longicornis } & 2 \\ \text { 6. Prenolepis sp. } & 21 \\ \text { 7. Iridomyrmex sp. } & 7 \\ \text { 8. Melanoplus bicolor } & 8 \\ \text { 9. Solenopsis geminata } & 33 \\ \text { 10. Tetramorium sp. } & 21\end{array}$

As can be seen from the above list, as many as 10 species of ants belonging to 9 genera were collected in a comparatively narrow area of a rice paddy (actually on the boundary) during comparatively short time. Considering the fact that ants are social insects, one specimen of ant collected afield implies that there were many of them. Thus, we can estimate from the above list that the total population of ants in the rice paddy was tremendous.

A report will be published on the ant fauna of rice paddies in Thailand.

(D) Stylopids

From Thailand, Kifune and Hirashima (1975) described a stylopid, Elenchus yasumatsui, which is parasitic on the white-backed planthopper and the brown planthopper based on the results of field studies by Dr. Yasumatsu and his Thai collaborators in the Chiang Mai area. Very recently this species was found from Sarawak also (Hirashima and Kifune, 1978). It is also parasitic on the white-backed planthopper in Sarawak.

According to Yasumatsu et al. (1975), Elenchus yasumatsui is an important parasite of the white-backed planthopper and the brown planthopper in northern provinces of Thailand.

We also collected both the adults and nymphs of the two rice hoppers parasitized by Elenchus yasumatsui in northern district of Thailand.

In addition, we collected by sweeping an adult and a nymph of the green rice leafhopper at Hin Kong and Kamphaeng Phet, respectively, which were parasitized by a stylopid. This stylopid is probably Halictophagus munroei Hirashima et Kifune described from Sarawak, where it parasitizes also Nephotettix nigropictus and Nephotettix virescens (Hirashima and Kifune, 1978). This is the first record of the stylopid parasitic on the green rice leafhopper from Thailand.

\section{(E) Pipunculid flies}

Flies belonging to the family Pipunculidae (Diptera) are known to be parasitic on Homoptera Auchenorrhyncha. In rice paddies, many species of this parasitic flies are found, and they are undoubtedly one of the natural controlling agency of rice leafhoppers and planthoppers. We found that at least 2 species of Pipunculus are fairly common in rice paddies in many locations in 
Thailand. In Tak, for example, 4-5 adult flies of Pipunculus were collected by every 90 sweeps in rice paddies.

Yano (1979) reports the results of his taxonomic study on our collection of the rice paddy dwelling pipunculid flies in Thailand. He recognizes as many as 10 species.

(F) Spiders and other predators

Spiders have been recognized as the important natural controlling agency over the increase of rice pests including rice leaf- and planthoppers (Kobayashi, 1961; Kiritani et al., 1972; Yasumatsu et al., 1975; Otake, 1977). Okuma (1968) and Okuma and Wongsiri (1973) recorded 59 species of spiders in total (13 families and 37 genera) from the rice paddies of Thailand. This is an amazing number of species. We also collected a number of species of spiders from the rice paddies in Thailand.

Yasumatsu et al. (1975) report 5 species of damselflies (Odonata: Agrionidae), i. e., Agriocnemis pygmaea, Agriocnemis dabreui, Ceriagrionolivaceum, Ischnura senegalensis and Aciagrion occidentale, are most important damselflies which attack rice pests such as the adult moths of defoliators and stem boreres, both nymphal and adult stages of leaf- and planthoppers, and the adults of gall midge. Nakao et al. (1976) list 33 species of damselflies and dragonflies from the rice paddies of Thailand. We also observed damselflies are abundant in rice paddies of Thailand.

Otake (1977) mentions some predatory species of rice hoppers other than spiders and damselflies. They include Microvelia (Hemiptera : Veliidae), various types of carnivorous beetles (Coleoptera) such as coccinellids, carabids and staphylinids, species of Nabidae (Hemiptera) and frogs. We also observed most of these species in Thai rice paddies.

(G) Microbial diseases*

Among microbial diseases, such as virus, bacterial, fungus, and protozoan diseases, a few pathogenic fungi have been isolated from leafhoppers and planthoppers (Paecilomyces farinosus (Morimoto, 195‘2; Aoki, 1957) and Beauveria bassiana (Shimazu et al., 1976) from leaf hoppers ; Entomophthora delfacis (Hori, 1905) and Conidiobolus sp. (Okada, 1971) from planthoppers).

Although the present knowledge on the infectious diseases of hoppers are poor, the utilization of fungi is promising for the microbial control of rice leaf- and planthoppers.

During the course of the present research (29 September-31 October 1977 at San Pa Tong Rice Experiment Station and 3 November-22 November 1977 at Chainat Rice Experiment Station), special attention was paid to the fungus

* Most of the experiments on the microbial diseases were carried out in Japa $n$ by Aizawa in collaboration with Mr. T. Shimazu, Mr. S. Shimizu and Dr. N. Fujiyoshi. 
diseases of the hoppers. It was difficult to find naturally fungus infected hoppers, however, hoppers which appeared symptom within short period after collecting of them from rice paddies were obtained. Among these materials, Beauveria bassiana and Paecilomyces farivtosus, particularly the former were isolated. The role of these fungi and the relationship between the frequency of the isolation of these fungi and the incidence of the diseases should be investigated much more in detail.

Aizawa et al. reported for the first time the existence of 3 serotypes in Beauveria bassiana. Generally, serotypes 1 and 2 are much more virulent than serotype 3 against the silkworm, Bombyx mori (Aizawa, Shimazu and Shimizu, 1976 ; Shimizu and Aizawa, unpublished). The pathogenicity of some insect pathogenic fungi was investigated against the green rice leafhopper, Nephotettix cincticeps.

1. Pathogenicity of Beauveria bassiana against the green rice leafhopper

Adults of the green rice leafhopper were released on the young rice plants in a rearing container and conidia suspension in $0.05 \%$ Tween 80 was

Table 1. Pathogenicity of entomopathogenic fungi against the green rice leafhopper.

\begin{tabular}{|c|c|c|c|c|c|c|c|c|}
\hline \multirow{3}{*}{ Fungus } & \multirow{3}{*}{$\begin{array}{c}\text { No. of } \\
\text { conidia } / \mathrm{ml}^{\mathbf{a}}\end{array}$} & \multirow{3}{*}{$\begin{array}{c}\text { No. of } \\
\text { adults used }\end{array}$} & \multicolumn{3}{|c|}{ Cumulative } & \multicolumn{3}{|c|}{ mortality $(\%)$} \\
\hline & & & & & ime $\mathrm{i}$ & in day & & \\
\hline & & & 2 & 3 & 5 & 6 & 8 & 10 \\
\hline Beauveria bassiana F 53 (serotype 3 ) & $4.6 \times 10^{7}$ & 21 & 0 & 0 & 28.6 & 52.4 & 90.5 & 95.2 \\
\hline Beauveria tenella & $5.1 \times 10^{5}$ & 20 & 0 & 10 & 10 & 20 & 25 & 25 \\
\hline Paecilomyces farinosus & $4.4 \times 10^{7}$ & 20 & 0 & 0 & 15 & 20 & 40 & 40 \\
\hline Paecilomyces $f$ umosoroseus & $5.2 \times 10^{6}$ & 22 & 0 & 4. 6 & 13. 6 & 22.7 & 27. 3 & 27.3 \\
\hline Nomuraea rileyi & $1.1 \times 10^{8}$ & 20 & 0 & 0 & 10 & 25 & 35 & 40 \\
\hline Control & - & 20 & 0 & 0 & 10 & 20 & 30 & 35 \\
\hline
\end{tabular}

a) Conidia suspension was sprayed.

Table 2. Virulence of Beauveria bassiana serotypes against the green rice leafhopper and the silkworm.

\begin{tabular}{|c|c|c|c|c|c|c|c|c|c|c|c|c|}
\hline \multirow{2}{*}{$\begin{array}{l}\text { Test } \\
\text { insect }\end{array}$} & \multirow{2}{*}{$\begin{array}{l}\text { Fungus } \\
\text { isolate }\end{array}$} & \multirow{2}{*}{$\begin{array}{c}\text { No. of } \\
\text { conidia } / \mathrm{ml}^{\mathrm{a}}\end{array}$} & \multirow{2}{*}{\multicolumn{2}{|c|}{$\begin{array}{c}\text { No. of } \\
\text { insects } \\
\text { tested }\end{array}$}} & \multicolumn{8}{|c|}{ Cumulative mortality (\%) } \\
\hline & & & & & 3 & 4 & $\begin{array}{l}\text { Time } \\
5\end{array}$ & $\operatorname{in}_{6}$ & days & 8 & 9 & 10 \\
\hline Green rice & $\mathrm{F} 45^{\mathrm{b})}$ & $5.4 \times 10^{6}$ & 20 & 0 & 10 & 10 & 30 & 70 & 90 & 100 & & \\
\hline leafhopper & $\mathrm{F} 21^{\mathrm{c}}$ & $3.5 \times 10^{7}$ & 19 & 0 & 5.3 & 5.3 & 5.3 & 10. 5 & 42. 1 & 52. 6 & 52.6 & 52. 6 \\
\hline (adult) & Control & - & 20 & 0 & 0 & 0 & 0 & 0 & 0 & 10 & 10 & 10 \\
\hline Silkworm & F45 & 3. $2 \times 10^{4}$ & 5 & 0 & 0 & 0 & 0 & 0 & 0 & 0 & 60 & 60 \\
\hline (4th instar & F21 & $6.2 \times 10^{4}$ & 5 & 0 & 0 & 0 & 0 & 100 & & & & \\
\hline larva) & Control & - & 5 & 0 & 0 & 0 & 0 & 0 & 0 & 0 & 0 & 0 \\
\hline
\end{tabular}

a) Conidia suspension was sprayed.

h) Beauveria bassiana serotype 2 .

c) Beauveria bassiana serotype 3 . 
sprayed. The most pathogenic fungus was Beauveria bassiana (serotype 3) as shown in Table 1.

The virulence of Beauveria bassiana serotypes 2 and 3 was compared by the spray method of conidia suspension. The result is shown in Table 2 and it was found that serotype 3 was much more virulent than serotype 2 against the green rice leafhopper. This tendency is considered to be an advantage in the utilization of Beauveria bassiana for the microbial control of hoppers in the sericultural countries.

2. Toxicity of Bacillus thuringiensis preparations for the green rice leafhopper

The following 3 Bacillus thuringiensis preparations were used: U. S. Standard (HD-1-S-1971; subsp. kurstaki; $3.00 \times 10^{10}$ spores/g), AY reference preparation (subsp.aizawai; $2.08 \times 10^{10}$ spores/g), and AF 101 reference preparation (subsp. softo ; $2.63 \times 10^{10}$ spores/g). Two $\%$ suspension of each preparation was sprayed on young rice plants and adults of the green rice leafhopper were released. Three preparations did not show the toxicity against the green rice leafhopper.

\section{OTHER ENTOMOLOGICAL ACTIVITIES AND OBSERVATIONS*}

\section{(A) General insect collecting}

(1) Doi Inthanon

On 12 October, we went to Doi Inthanon, $2,565 \mathrm{~m}$, which is the highest peak in Thailand. We started San Pa Tong at about 9: 00 a.m. by a Landrover and reached at the summit of the mountain at about noon. The road was good. As we proceeded to the summit, it got cooler and cooler, and it was cold on the summit. On the summit, there was a monument and a large radar site which was guarded by soldiers.

No insect collecting was allowed in the national park zone. Only observations. On the summit, we carefully searched after ants on the ground and plants, but completely none of them was seen! Very quiet. However, a number of workers of Bombus were visiting flowers and small and fragile insects were seen on plants.

About the foot of the mountain and just outside the national park zone, there was a large waterfall which was surrounded by forests. This place was good for collecting butterflies, ants, stingless bees and others.

This waterfall was again visited on 19 October. No good collecting was made except ants. A species of sucking lice was taken from water buffaloes which were grazing around near the river.

(2) Doi Sutep

* T. Wongsiri is not responsible to this chapter. 
Highland Agricultural Experiment Station which is located near the summit of Doi Sutep, at about 1,200 m in altitude, was visited on 21 October. This station was situated in a good environment. Many Bombus workers of one species were visiting flowers, and several Megachile females were also taken on the same flower. Many species of ants were also collected.

(3) Fang

Insects were collected in the site for Fang Agricultural Experiment Station and nearby forests during our visit to this place from 23 October to 27 October. This place was visited by us in 1973 also. A number of Japanese entomologists including Dr. S. A sahina ( $N$ ational Institute of Health, Tokyo), Dr. K. Morimoto (Kyushu Univ.), Prof. R. Kano (Tokyo Medical and Dental Univ.), Prof. H. Mori (Hokkaido Univ.), Dr. K. Nohara (Hagi Citrus Exp. St.), Prof. S. Nakao (Kurume Univ.), Prof. K. Yano (Yamaguti Univ.) and others also visited this place before. Thus, this place is well known to Japanese entomologists as one of the good sites for insect collecting in Thailand. Indeed this place abounds in butterflies including Troides, bees, ants, beetles, etc. In addition, it was fun to bathe in a small open hot spring in front of the guest house.

One night we tried to catch nocturnal insects by bait which was tnade of whisky, honey and sugar. We put the bait on tree trunks or the surfaces of large stones in the evening, and watched for insect visitors at midnight with a torch. Only one large black moth other than ants was taken. It was unexpectedly poor hunting. However, on one tree trunk in front of the guest house, at our great surprise, we observed tens of thousands of ants (Crematogaster) attracted to the bait! Apparently these numerous ants came out from the inside of the tree where they nest. They had eaten the bait and disappeared till dawn and no one ant was seen at the same place in the morning. We put more bait on the same tree trunk in the morning but no ant was seen in the day time. Instead, we collected a number of workers of a large fulvous-colored stingless bee which were attracted to the bait.

Another experience with the ant genus Tetraponera in Fang is stated below. Bingham (1903). in The Fauna of British India, describes the virulence of ant species Simarufonigra (now known as Tetraponera), as follows: "This species is the most virulent of any ant known to me, its sting being most painful and sometimes causing considerable inflammation. Mr. G. A. James Rothey, in a paper in the Trans. Ent. Soc. London, 1889, p. 353, gives a vivid account of the severe pain caused to him by the sting of one of this species." We noticed that native people in Fang already knew that the sting of this species, Tetraponera rufonigra, is very painful. One evening, while he was out collecting ants in Fang, Hirashima got a sting on the finger by one of the smaller and black species of Tetraponera. At the moment, a great shock with severe pain run from his hand to his head. He almost could not stand for a 
few minutes and run about the place as he rubbing his finger. About $10 \mathrm{~min}$ utes elapsed until he took up the insect net again. The sting caused a small necrosis for about ten days.

(4) Khao Yai

Khao Yai National Park is located about $120 \mathrm{~km}$ north-east of Bangkok. A Z-day trip to Khao Yai was started on the morning of 13 December, accompanied by Dr. Yasumatsu, Mrs. Tanongchit, Dr. Angoon, Mr. Saner and Mr. A roon. The latter is a famous butterfly collector. The drive to Khao Yai was pleasant and we enjoyed it very much. Khao Yai means a big mountain, and was a beautiful place. After arrival at Khao Yai National Park Mortor Lodge, we went to Khao Khieo, which means a green mountain and is a next peak to Khao Yai, for collecting insects. Next morning we collected insects on Khao Yai at about the elevation of $800 \mathrm{~m}$. Insects were not many in this place. Very curiously, we noticed a freshwater mussel can produce sounds. We happened to hear sounds produced by that creature at the wild life observatory in the late evening of the first day. At first, we thought some smaller toads were croaking in a pond in front of the observatory. We were told, however, it was a kind of freshwater mussel! The sounds were not loud but fairly clear, and intermittent just like croaks of toads. Next morning we also happened to know the creature was making sounds in the mountain stream.

\section{(B) Insects for human consumption}

Bristowe (1932) and Nakao (1964) reported interesting observations on insects for human consumption in Thailand. The following notes are made based on our experience.

(1) Cricket

We witnessed in Chiang Mai that crickets were sold at the market. The cricket was Brachytrupes portentosus Lichtenstein. A shopkeeper used to pick up a cricket from a plastic bag, in which he kept many of them alive, to spit it longitudinally from the head to the abdomen, 3 or 4 crickets in one small bamboo stick. He then fried them in oil in front of shoppers. We bought and tried. It was well edible, having a taste somewhat similar to shrimp. Bristowe (1932) says that "... but personally I find them (Gryllus testaceus and Brachytrupesportentosus) insipid and lacking in any flavour that I could define." We agree with him to some extent.

(2) Giant water bug

Tourists were curious to see the giant water bug, Lethocerus indicus, which was displayed for sale at the Sunday market in Bangkok. Shopkeepers display many of bugs, which were boiled in hot water, in a large bamboo basket, some were beautifully arranged in rows, for sale (Plate 1, Figs. 3, 4). We learned that the bugs are consumed in two ways. They are eaten after fried in oil or used as one of seasonings for a sauce which is served for fried fish, 
especially the catfish. One of us tried this dish at Chiang Mai and he liked it because of a rich taste. Shoppers were used to stick a toothpick, which was served by the shopkeeper, in the abdomen of the bug and then smell it in order to buy a good one. Good one means the bug which has a stronger and better flavor. Usually the male bug is more attractive, but the female bug is also sold. The price was 1 baht for 1 bug in 1973, while it was 5 baht in 1977.

(3) Honey bees' productions

There was a small shop in Chiang Mai specialized for honey and bee's wax. This shop kept a small colony of Apis indica, with a few hundred workers, near the counter for attraction. A bottle of honey, about $720 \mathrm{ml}$, of good quality having beautiful color and good taste, was a little more expensive than a bottle of the same size of Jonnie Walker Red Label, the imported Scotch whisky which was sold at the department store in Chiang Mai. Probably this honey was taken from Apis indica. Honey of ordinary quality, darker in color, was much cheaper. We paid 70 baht for 1 bottle of the same size. Bee's wax was valued 42 baht for $550 \mathrm{~g}$.

We also seen a comb of Apis florea sold at the Sunday market in Bangkok (Plate 1, Fig. 5). It contained many of the larvae and pupae and also a few of adults of florea in addition to honey. This is also served for dish.

It is very characteristic to Apis florea that the worker bee holds the wings folded on the thorax when her visited flower like Andrena females do (Plate 1, Fig. 6).

(C) A small collection of Thai names for insects

Thai names for some popular insects are shown below, although the Thai pronunciation is very difficult.

$\begin{array}{ll}\text { (English) } & \text { (Thai) } \\ \text { Ant } & \text { Mot } \\ \text { Aphid } & \text { Plia On } \\ \text { Bee (Honey bee) } & \text { Phung } \\ \text { Beetle } & \text { Duong } \\ \text { Buttterfly } & \text { Phi Sua } \\ \text { Cicada } & \text { Chaka Chan } \\ \text { Cockroach } & \text { Malaeng Sap } \\ \text { Cricket } & \text { Jinrit (Ching Reed) } \\ \text { Dragonfly } & \text { Malaeng Por } \\ \text { Giant water bug } & \text { Maeng Da } \\ \text { Grasshopper } & \text { Takka Tan } \\ \text { House fly } & \text { Malaeng Wan } \\ \text { Insect } & \text { Malaeng } \\ \text { Mosquito } & \text { Yung } \\ \text { Moth } & \text { Phi Sua Klang Khun }\end{array}$


Praying rnantid

Silk worm

Spider

Stink bug

Termite

(Flying termites
Takka Tan Toy Muai

(Takka Tan Tam Khao)

Non Mai

Mang Mum

Malaeng Sing

Pluak

Malaeng Mao)

\section{(D) Entomological publications}

In 1977, a butterfly book written in English was published in Bangkok. It is "Field Guide to Butterflies of Thailand", written by Dr. Boonsong Lekagul (naturalist), Miss Karen Askins (biologist and text revisor), Mr. Jarujinta Nabhitabhata (entomologist) and Mr. Aroon Samruadkit. Mr. Aroon is a technician working for the Entomology Section of the Department of Agriculture in Bangkhen, Bangkok. $\mathrm{He}$ is a famous butterfly collector in Thailand, as stated elsewhere in this paper. It is said that most of the specimens appearing on the plates of this book were collected by him (and also kept at the Entomology Section in Bangkhen under the care of Dr. (Miss) Angoon Lewvanich). In this book, 630 species of Thai butterflies are well illustrated in color. This is 'a welcome book to the knowledge of the butterfly fauna of Thailand. Publisher: Association for the Conservation of Wildlife, 4, Old Custom House Lane, Bangrak, Bangkok 5. 150 baht for 1 copy.

Another butterfly book of English text, Butterflies in Thailand, Volume 1, Papilionidae and Danaidae, was revised and published also in 1977 by the Viratham Press, Thailand. The first edition of this book was appeared in 1974. In the revised edition, 58 species of Papilionidae and 36 species of Danaidae are nicely illustrated in color. This is also a fine book and a welcome contribution to the Thai butterflies of the two families. US $\$ 7$ for 1 copy.

\section{(E) An observation on a mimicking butterfly}

The following observation was made by Hirashima on 25 November 1973 at Chiang Dao, when he visited this place, accompanied by Prof. H. Mori (Hokkaido Univ.), Dr. K. Nohara (Hagi Citrus Exp. St.) and Dr. Amornrut Bhandhufalck (Dept. Agr., Bangkok), for the field study of insects conducted by the overseas research project "Field survey on the biological control of rice stem-borers, aphids, diaspine scales and phytophagous mites in S. E. Asia."

He noticed several butterflies of Spindasis syama (Horsfield)* were visiting flowers of a weed of Polygonaceae while he was collecting bees on the same flower which were abundant in a citrus groove along the highway. Then he enjoyed to see this small pretty butterfly flying over flowers for a while. All of a sudden, surprisingly enough, some of them which were walking on

* Prof. T. Shirôzu of Kyushu Univ. kindly identified this species. 
flowers stopped and took an upside-down posture on the plant simultaneously. He could not understand at first what does it implies. He continued to watch them. When a small flock of small birds flew over the weed, about $2 \mathrm{~m}$ high, butterflies which were sucking nectar or walking on flowers and leaves of the weed suddenly stopped and took the very posture (Plate 1, Fig. 2). The butterfly did not move at all, extended straight its antennae downwards while its anal apex of the hind wing as well as the tail fringes were stretched upward. Then Hirashima was impressed that the butterfly was taking a mimicking posture to flower or something. Most probably this is not a usual resting posture of this butterfly. According to the butterfly book mentioned above, this species occurs in India to Thailand, China, and Taiwan, south to Malaya. Wickler (1968) reports a similar habit in Theclalinus, also a lycaenid butterfly of Trinidad.

\section{Selected references}

(a) Parasitic insects and predators

Hirashima, Y. and T. Kifune (1978) Strepsipterous parasites of Homoptera injurious to the rice plant in Sarawak, Bornero, with description of a new species (Notulae Strepsipterologicae-III). Esakia, (11) : 53-58.

Kifune, T. and Y. Hirashima (1975) A new species of the genus Elenchus from Thailand (Strepsiptera : Elenchidae) (Notulae Strepsipterologicae-II). Mushi,48(12): 145-148, 2 pls.

Miura, T. (1976) Parasitic activity of Paracentrobia andoi (Ishii) and Gonatocerus sp. (Hymenoptera: Mymaridae), two egg parasites of the green rice leafhopper, Nephotettix cincticeps natural enemies of leafhoppers 2).

Fac.Agr., $\quad S h$ i ma $n$ e (10\$ $n$ 49t55., (In Japanese with English summary) nymphal parasites of rice le a f -

21-44. result of field st udie $\mathrm{s}$ i $\mathrm{T}$ h a i l a n d i n 1977 .

$$
\text { F. N a k a s uji }\left(\begin{array}{llll}
1 & 9 & 7 & 2
\end{array}\right) \quad \text { Q u a n t i t a t i ve e va } 1
$$

predation by spiders on the green rice leafhopper,

$\mathrm{Uh} 1 \mathrm{e} \mathrm{r}$, b y a sight-count method. Res. Popul. Ecol. (Kyoto), 13(2): 187-200.

Kobayashi, T. (1961) The effect of insecticidal applications to the rice stem borer on the Byogaichu Hassei-Yosatsu Special Report No. 6 (126

Kurumedoniw $r$. , 25(2):

Okuma,

Mushi,42(8): 89-118, 6 pls.

Okuma,

Otake,

Plant-

hopper, 
Yano, K. (1979) Faunal and biological studies on the insects of paddy fields in Asia. Part II. Illustrated key to the Thai species of Pipunculidae (Diptera). Esakia, (13): 45-54.

Yasumatsu, K., T. Wongsiri, S. Navavichit and C. Tirawat (1975) Approaches toward an integrated control of rice pests. Part 1: Survey of natural enemies of important rice

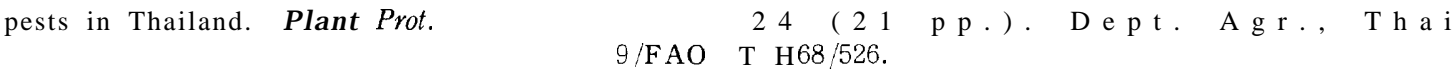

(b) Microbial diseases

Aizawa, K.. T. Shimazu and S. Shimizu (1976) Pathogenicity of microorganisms to storedProc U)ibt-Japan Seminar on Stored Product Insects (Manhattan, Kansas, January 5-8, 1976), pp. 59-67.

Aoki, K. (1957) p p. G i ho d o, T o k y o. ( I n J a p a e s e )

Hori, S. (1905) Entomogenous fungi of Japan (II). Entomological Magazine, 3: 81-83.

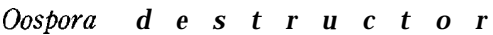
farinosa(Dicks.)
Spicariarubido-purpurea A ki, Isaria

Kochirch Reports 1(13) : 15-22.(In

Okada, T. (1971) An entomophthoraceous fungus, Conidiobolus sp., separated from planthoppers, Laodelphax striatellus (Fallen) and Nilaparvata lugens (Stàl). Proc. Assoc. Plant

( I $\mathrm{n}$ J a p a ne se wi th Engli s h s u m m a r y )

Shimazu, T., S. Shimizu and K. Aizawa (1976) Pathogenicity of entomopathogenic fungi particularly a g a i n s $t \quad$ s o m e Abstract of Annual Meeting of Japanese Society of Applied Entomology and Zoology, p. ( I n J a p a n e s e )

(c)

Socns. Ent.

Kurume. (1964) The customs connected with the insects in Thailand.

13: 81-85, 3

Wickler,

Mimicry in plants and animals. 


\section{Explanation of Plate 1}

Fig. 1. A sketch of rice paddy in San Pa Tong.

Fig. 2. A lycaenid butterfly, Spindasis syama, which is supposed to be in a mimicking posture.

Fig. 3. Giant water bug displayed for sale at the market in Bangkok.

Fig. 4. A Thai girl shopping the giant water bug at the market in Bangkok.

Fig. 5. A comb of Apis florea displayed for sale at the market in Bangkok.

Fig. 6. A worker of Apis florea visited a wild flower. Note the wings were folded on the thorax. 

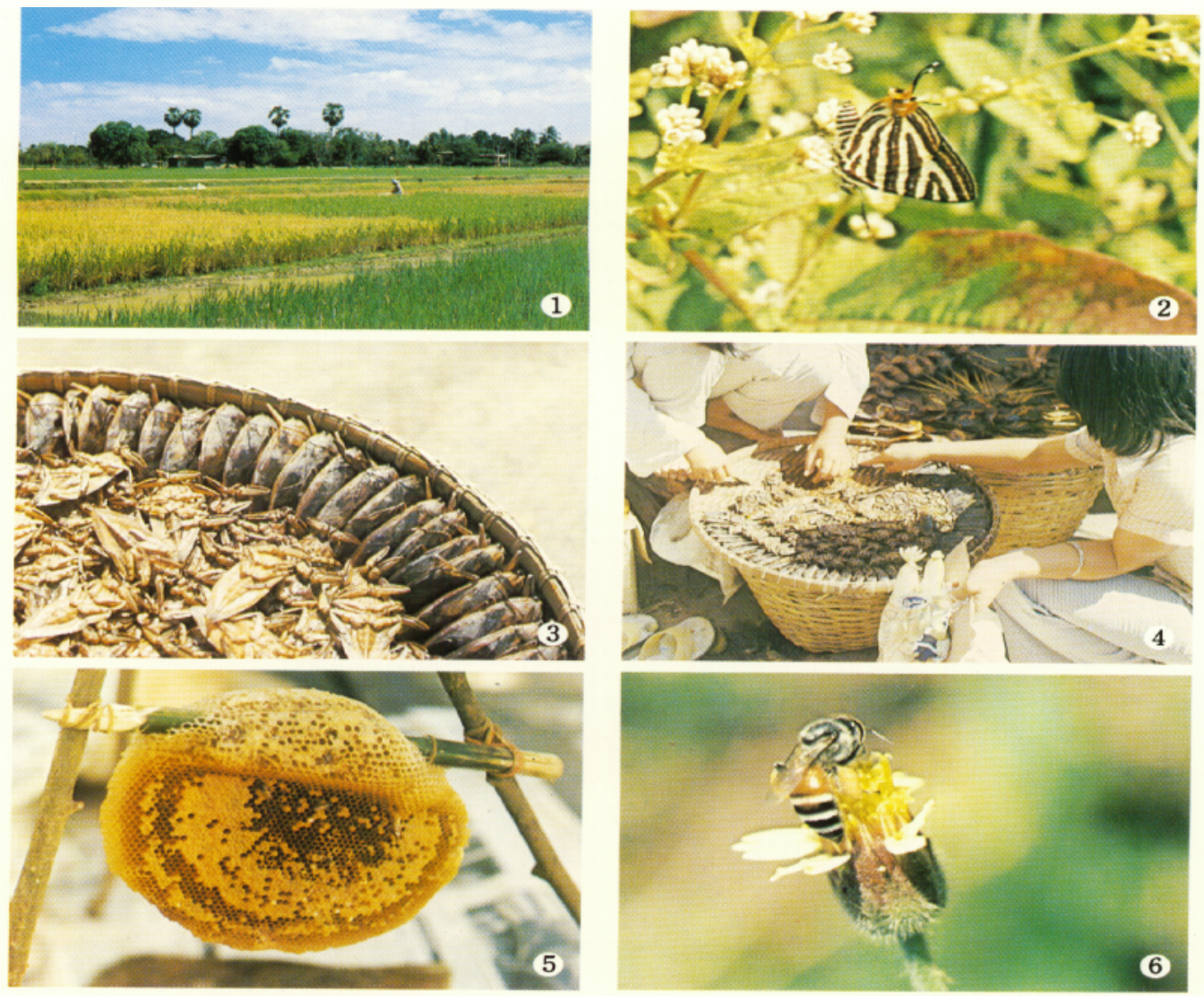

Hirashima, Aizawa, Miura and Wongsiri— Overseas Field Research 